\title{
Fluorescent Nitrones for the Study of ROS Formation with Subcellular Resolution
}

\author{
Stefan Hauck, Yvonne Lorat, Fabian Leinisch, Christian Kopp, \\ Jessica Abrossinow and Wolfgang E. Trommer
}

Additional information is available at the end of the chapter

http://dx.doi.org/10.5772/39122

\section{Introduction}

Reactive oxygen species (ROS) are the prize we are paying for an energy-efficient life under oxygen. They play a role in many diseases such as atherosclerosis, hypertension, ischemiareperfusion injury, inflammation, type- 2 diabetes, certain neurodegenerative diseases, even cancer and, certainly, aging (Kohen \& Nyska, 2002). Among these ROS are several radicals such as the hydroxyl, peroxy, alkoxy as well as the superoxide anion radical (Boveris, 1977). Direct measurement of the radicals is hampered by their short half lifes in the range of nanoto microseconds. They can, however, be trapped by addition to nitrones leading to relatively stable nitroxides with $t \frac{1}{2}$ of minutes (Janzen, 1971). Respiring mitochondria are a major source of ROS, particularly of the superoxide anion radical, which is formed in complexes I and III (Cadenas \& Davies, 2000; Dröge, 2002; Inoue et al., 2003; Turrens, 2003).

A couple of years ago we have described the synthesis and first application of a fluorescent nitrone composed of tert-butyl-nitrone and a $p$-nitro-stilbene moiety, which can be used for the detection of ROS with subcellular resolution. Short-lived radicals add to the nitrone under formation of a nitroxide radical which then quenches the fluorescence of the $p$-nitrostilbene (Hauck et al., 2009).

Similar double labels have previously been synthesized or at least suggested, partially in collaboration with us. Likhtenshtein and Hideg suggested in the eighties to couple nitroxides to a fluorophore which will become fluorescent only after reduction of the nitroxide moiety in viable biological systems (Bystryak et al., 1986). Hideg used fluorescent pyrrolines which can be oxidized to nitroxides mainly by singlet oxygen (Kalai et al., 1998). Rosen and collaborators investigated a fluorescent nitrone much like ours composed of nitrobenzene instead of nitrostilbene. The authors did not observe a decrease in the fluorescence upon reaction of the nitrone with $\alpha$-hydroxyethyl radicals which was probably due to an only very small concentration of the nitroxide formed in this reaction (Pou et al., 
1995). To the best of our knowledge, this work has not been continued. Somewhat different approaches for the detection and trapping of ROS were taken by Bottle et al., 2003, Heyne et al., 2007 and Blough et al., 1988.

Here we describe some extended studies with the $p$-nitrostilbene-tert-butyl-nitrone $(\underline{\mathbf{1}})$ under a variety of physiological conditions i.e., employing inhibitors of components of the respiratory chain, the $\mathrm{F}_{1}-\mathrm{F}_{0}-\mathrm{ATP}$ synthase and the membrane potential as well as similar studies with a corresponding coumaryl-styryl-tert-butyl-nitrone derivative (2) and finally, a third compound based on 4-pyrrolidine-1,8-naphthylimido-methylbenzene as fluorophore ( $\underline{3})$.

\section{Results and discussion}

\section{1. $p$-Nitrostilbene-tert-butyl-nitrone, $\underline{1}$}

Fig. 1 shows the reaction of the previously employed fluorescent nitrone $\underline{1}$ with the hydroxyl radical under formation of the corresponding nitroxide. The hydroxyl radical was generated by the Fenton reaction and the product extracted from the aqueous phase with degassed ethyl acetate yielding an EPR spectrum composed of 6 lines typical for hydroxyl radical adducts (Hauck et al., 2009).

When cultures of various cell lines, i.e., HeLa, COS 7 and $\mathrm{CHO}$, were incubated with $\underline{\mathbf{1}}$ and subsequently washed, it had almost exclusively accumulated in mitochondria as shown by co-staining with tetramethylrhodamine ethylester (TMRE, Farkas et al., 1989) and confocal laser spectroscopy (Fig. 2). Without any further addition the fluorescence slowly decreased to almost none within about $20 \mathrm{~min}$. However, generation of hydroxyl radicals by the Fenton reaction (Walling, 1975) reduced this time to $20 \mathrm{sec}$ (Fig. 3, Hauck et al., 2009). Similar results were obtained in presence of the complex I and III inhibitors, rotenone and antimycin A, but within a timeframe of 40 to $60 \mathrm{sec}$. Under these conditions both complexes are known to produce substantial amounts of the superoxide anion radical (Dlaskova et al., 2008; Han et al., 2001). In these early studies a quasi-confocal microscope was used (Axiovert 440, equipped with an ApoTome, Carl Zeiss, Jena) which has broad bandwidth filters, only. Thus, not allowing for monitoring small shifts in the emission spectra of $\underline{\mathbf{1}}$ upon addition of the radical as had been observed in cell-free controls.

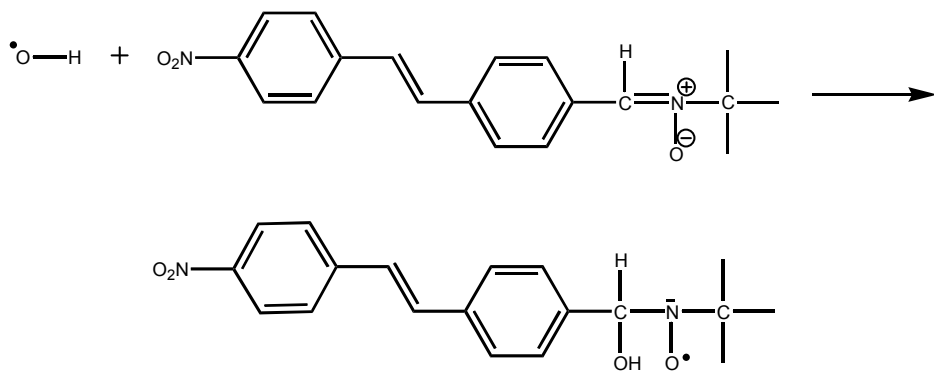

Figure 1. Structural formula of the $p$-nitrostilbene-tert-butyl-nitrone $\underline{1}$ and its reaction with the hydroxyl radical 

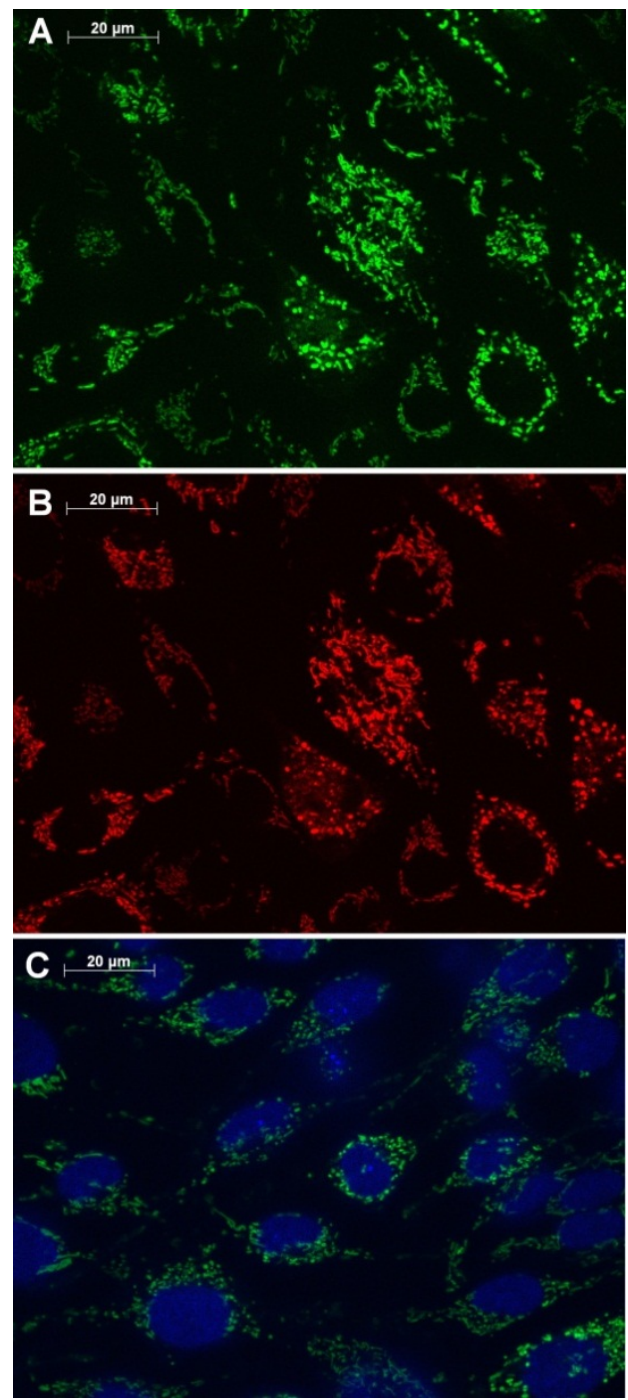

With kind permission from Springer Science + Business Media: Appl. Magn. Reson., p-Nitrostilbene-tert-butyl-nitrone: A novel fluorescent spin trap for the detection of ROS with subcellular resolution, vol. 36 (2009), p. 143, Stefan Hauck, Yvonne Lorat, Fabian Leinisch, Wolfgang E. Trommer, Fig. 8

Figure 2. COS cells incubated with $\underline{\mathbf{1}}(\mathbf{A})$ or with TMRE (B). The same cells were stained for DNA in the nuclei with DAPI $\left(C, \lambda_{\mathrm{abs}}=340 \mathrm{~nm}, \lambda_{\mathrm{em}}=504 \mathrm{~nm}\right)$, and also with $\underline{\mathbf{1}}\left(\lambda_{\mathrm{abs}}=388 \mathrm{~nm}, \lambda_{\mathrm{em}}=504 \mathrm{~nm}\right)$

The accumulation of $\underline{\mathbf{1}}$ in mitochondria came unexpected but is possibly due to an effect previously observed with so-called Skulachev ions, derivatives of ubiquinone or plastoquinone with long hydrophobic side chains composed of up to 10 isoprene units and a positively charged triphenylphosphonium group at the end, e.g., SkQ1 as introduced by Vladimir Skulachev. The positive charge is not localized but spread over the aromatic rings, thus 
allowing for membrane permeation due to the already negative potential of cells with respect to their outside and even more so of mitochondria, the only human organelle with a negative potential with respect to the cytoplasm. Once inside, they are trapped by the opposite potential outside (Severin et al., 2010). Similar effects have been observed with certain amphiphilic dipolar compounds to which $\underline{1}$ could belong (M.V. Skulachev, personal communication).
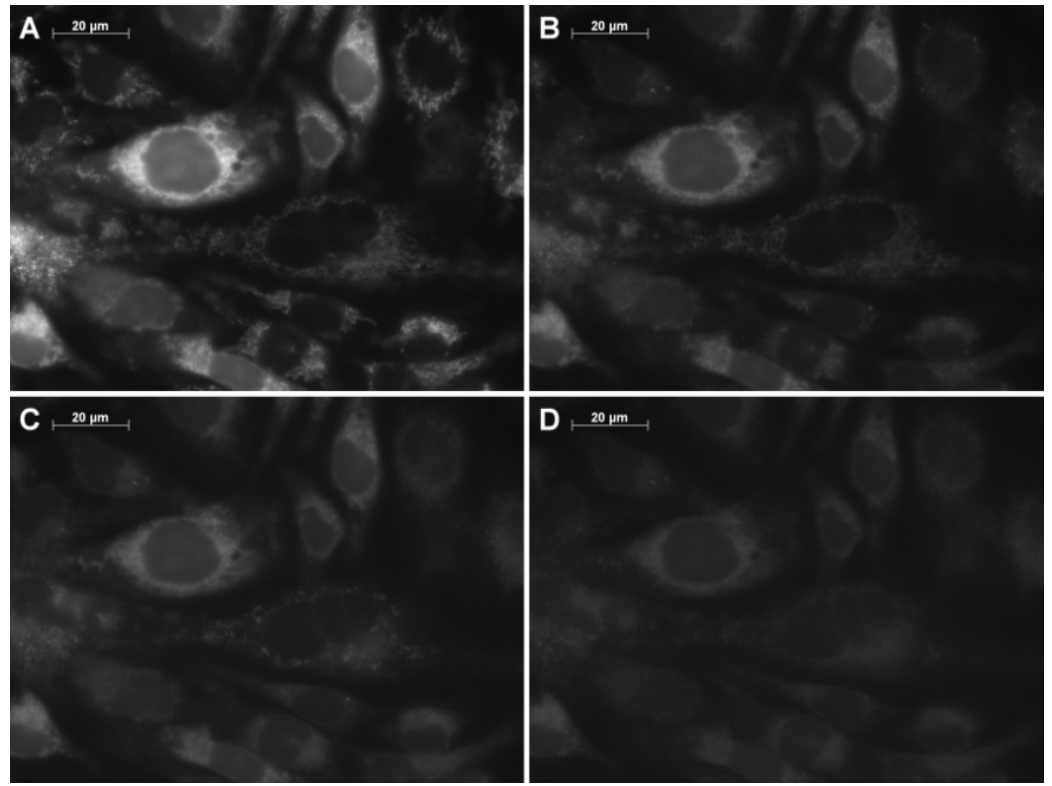

With kind permission from Springer Science + Business Media: Appl. Magn. Reson., p-Nitrostilbene-tert-butyl-nitrone: A novel fluorescent spin trap for the detection of ROS with subcellular resolution, vol. 36 (2009), p. 145, Stefan Hauck, Yvonne Lorat, Fabian Leinisch, Wolfgang E. Trommer, Fig. 10

Figure 3. Fluorescence decay of $p$-nitrostilbene-tert-butyl-nitrone $\underline{\mathbf{1}}$ in CHO cells: A: $0 \mathrm{sec}$, B: $5 \mathrm{sec}, \mathbf{C}: 10$ sec, D: $20 \mathrm{sec}$ after addition of $20 \mu \mathrm{l}$ each of $10 \mathrm{mM} \mathrm{Fe}^{2+}$ and $10 \mathrm{mM} \mathrm{H}_{2} \mathrm{O}_{2}$ (Fenton reaction)

The fluorescence half-life of $\underline{1}$ in mitochondria was studied under a variety of conditions. Data are summarized in Table I together with those from the coumaryl derivative $\underline{2}$. But why look for another double label? 1 has an absorption maximum at $383 \mathrm{~nm}$ which is well separated from the emission at $568 \mathrm{~nm}$. However, only recently have confocal laser microscopes been equipped with lasers of $405 \mathrm{~nm}$, most commercial instruments operate at $480 \mathrm{~nm}$ and above, rather outside the absorption range of $\underline{\mathbf{1}}$. Moreover, stilbenes as fluorophores pose yet another problem, cis-trans isomerization upon irradiation leading to a substantial shift in emission wavelength which is accompanied by photobleaching and also recovery rendering interpretation of data more complex (Fig. 6).

\subsection{Coumaryl-styryl-tert-butyl-nitrone, $\underline{2}$}

2-(4-Trifluoromethyl-2-oxo-2H-chromen-7-yl)-E-vinyl-1-(N-(1,1-dimethyl))-phenyl-4-nitrone $\underline{\mathbf{2}}$ was synthesized according to the scheme shown in Fig. 4. 
Unexpectedly, the absorbance and fluorescence properties of $\underline{\mathbf{1}}$ and $\underline{\mathbf{2}}$ do not differ very much as shown in Fig. 5, A \& B.
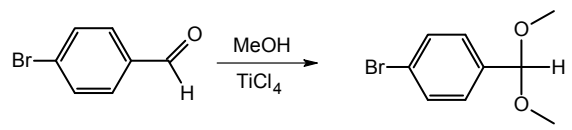<smiles>Nc1ccc2c(Br)cc(=O)oc2c1</smiles>

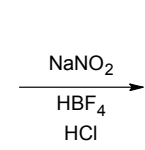

A + B $\underset{\mathrm{MeOH}}{\stackrel{\mathrm{Pd}(\mathrm{OAc})_{2}}{\longrightarrow}}$

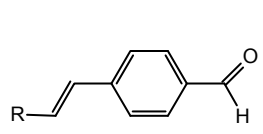

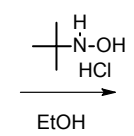
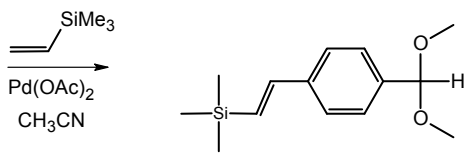

A

Figure 4. Synthetic scheme for the synthesis of $\underline{\mathbf{2}}$<smiles>N#[N+]c1ccc2c(C(F)(F)F)cc(=O)oc2c1</smiles>

B
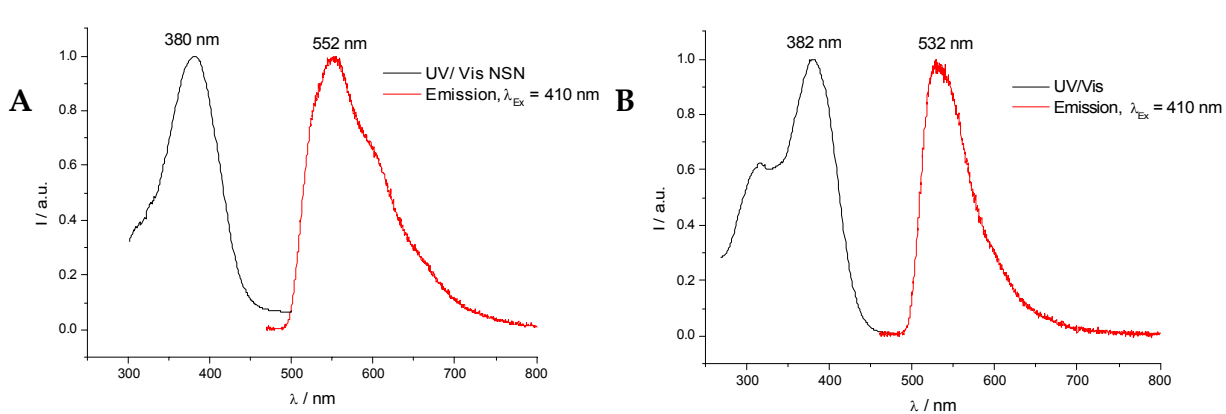

Figure 5. Absorption and emission spectra of $\mathbf{A}, p$-nitrostilbene-tert-butyl-nitrone $\underline{\mathbf{1}}$ and $\mathbf{B}$, cumarylstyryl-tert-butyl-nitrone $\underline{2}$ excitation at $410 \mathrm{~nm}$

Whereas $\underline{1}$ undergoes substantial photobleaching upon irradiation at $310 \mathrm{~nm}$ for $1 \mathrm{~min}$ (Fig. 6 B), the fluorescence of $\underline{\mathbf{2}}$ is almost completely stable under these conditions (Fig. 6 A). However, $\underline{1}$ recovers rather quickly reaching about $40 \%$ of the initial fluorescence within $4 \mathrm{~min}$ (Fig. $6 \mathrm{C}$ ).

Unfortunately, $\underline{\mathbf{2}}$ turned out to be far more toxic to cells in comparison with $\underline{\mathbf{1}}$. Growing adherent MCF-7 cells, a human breast adenocarcinoma cell line, were exposed to these compounds for three days. After fixation of viable cells with trichloroacetic acid, the damaged cells were removed by washing and cell proteins of the remaining cells were stained with sulforhodamine and measured photometrically at $570 \mathrm{~nm}$ (Skehan et al., 1990). In a rough estimate assuming sigmoidal behavior in a semi-logarithmic plot the half maximal dosis, IC 50 , of $\underline{\mathbf{1}}$ was about $300 \mu \mathrm{M}$ as compared to $40 \mu \mathrm{M}$ for $\underline{\mathbf{2}}$. Simultaneous irradiation at $366 \mathrm{~nm}$ for $3 \mathrm{~min}$ further reduced this value to $30 \mu \mathrm{M}$. The known toxicity of coumarin may play a role here (Fig. 7, A \& B; Oodyke, 1974). Therefore spin-trapping experiments in the presence of inhibitors were primarily carried out with $\underline{\mathbf{1}}$. However, $\underline{\mathbf{2}}$ may be employed as well by using lower concentrations of 10 to $20 \mu \mathrm{M}$. 

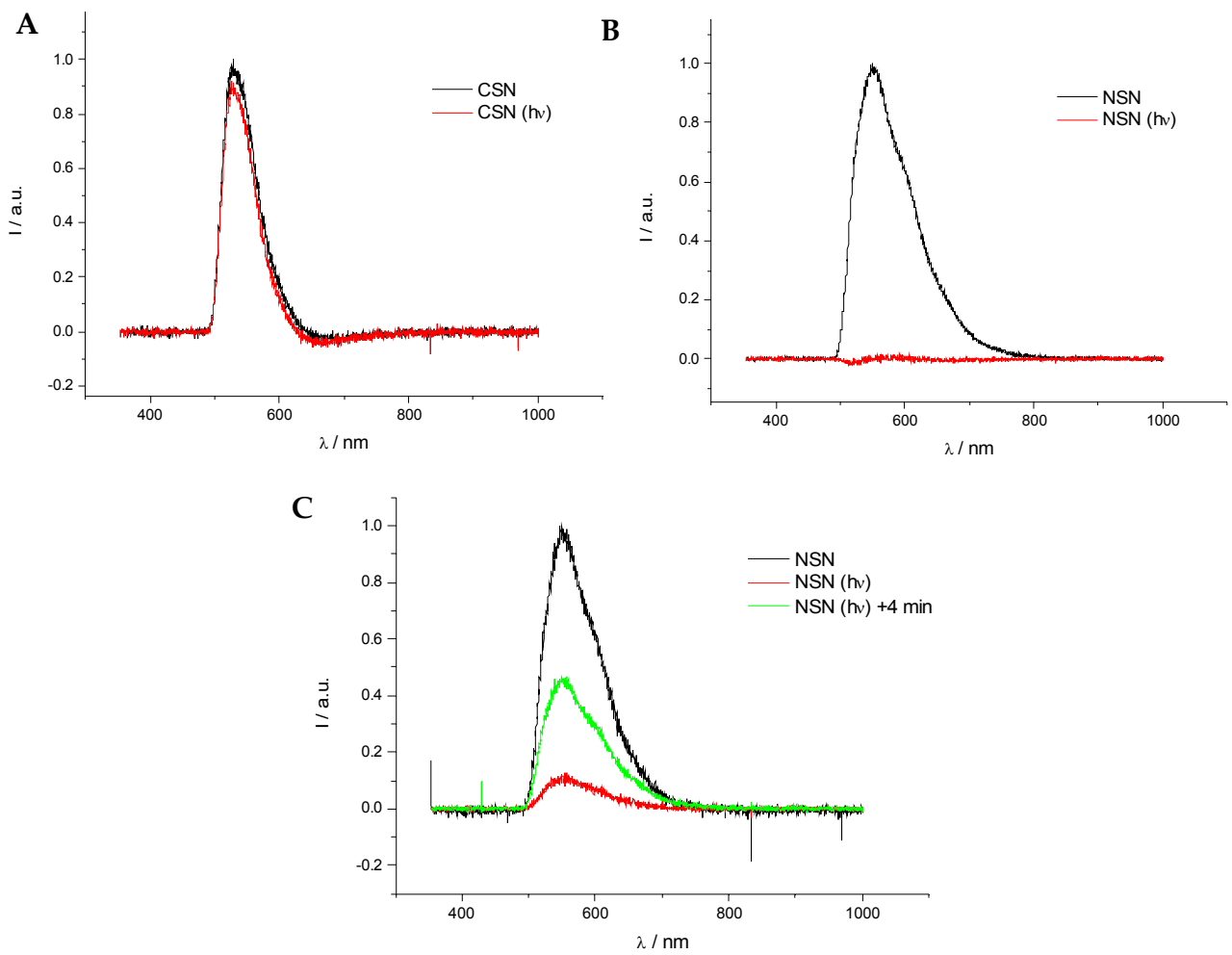

Figure 6. Photobleaching of $\underline{\mathbf{2}}$ (CSN, A) und $\underline{\mathbf{1}}$ (NSN, B) upon irradiation at $310 \mathrm{~nm}$ for $1 \mathrm{~min}$. The recovery of $\underline{\mathbf{1}}$ with time is shown in panel $\mathbf{C}$.
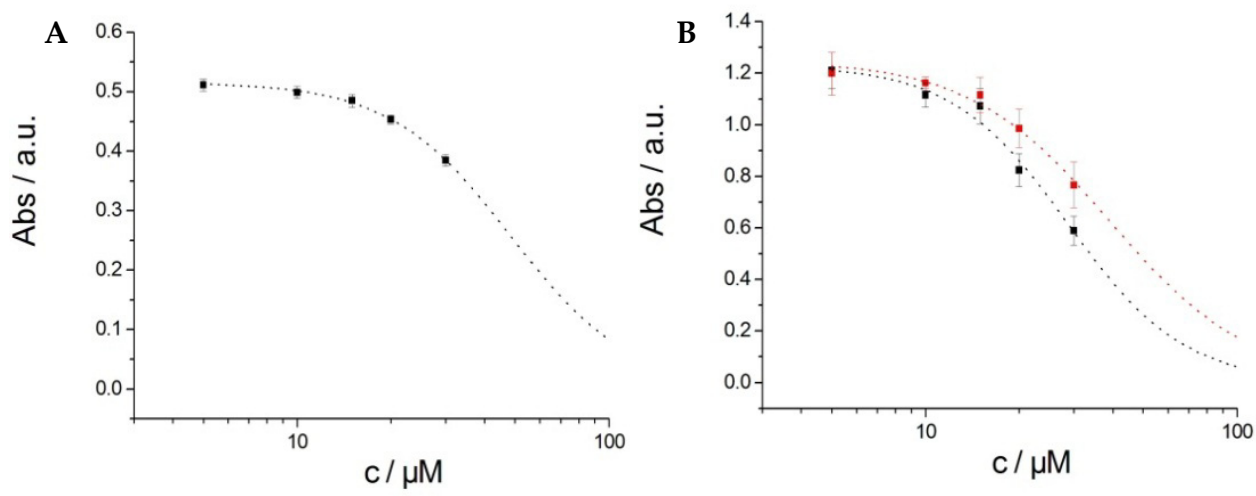

Figure 7. Cytotoxicity of $\underline{\mathbf{1}}(\mathbf{A})$ and $\underline{\mathbf{2}}$ (B) as determined in MCF-7 cells after a three days exposure. B, lower trace upon additional irradiation at $366 \mathrm{~nm}$. 
The effect of rotenone as inhibitor of complex I of the respiratory chain on the formation of the superoxide anion radical formation in HeLa cells (Hauck et al., 2009) was followed with $\underline{2}$ (Fig. 8). The initial fluorescence and after 100 or $90 \mathrm{sec}$, respectively, is shown in the absence and presence of rotenone. The time course of this decay as measured in $0.5 \mathrm{sec}$ intervals is shown as well. Clearly, inhibition of complex I significantly increases ROS formation. The figure also reveals that the intracellular distribution of $\underline{\mathbf{2}}$ is not as enriched in mitochondria as had been found with $\underline{1}$. Evidence that quench did not result, or at least not largely, from photobleaching came from experiments in which the shutter was closed during measurements. However, some non-specific redox reactions cannot be excluded.
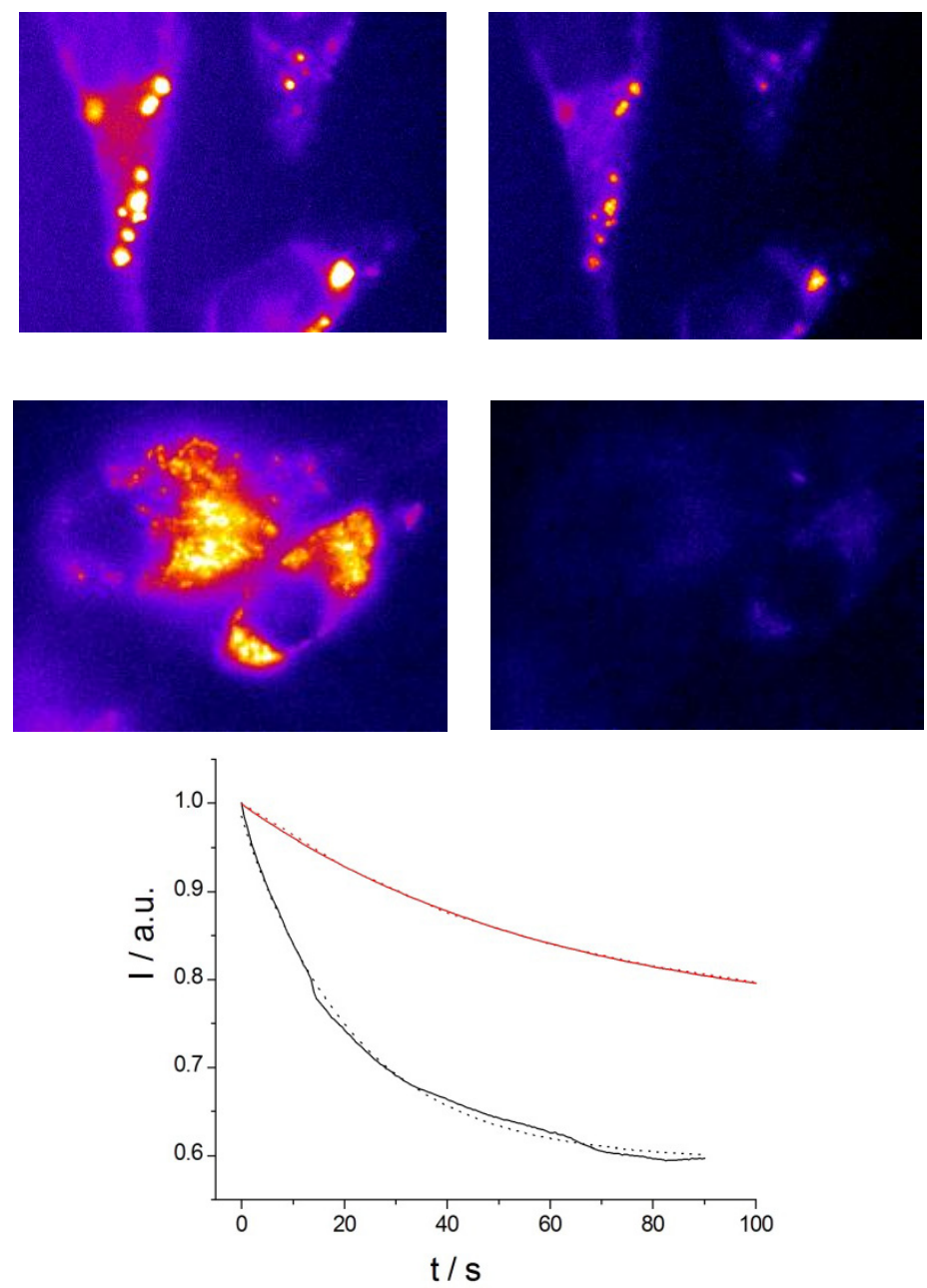

Figure 8. False color representation of the fluorescence decay of $\underline{\mathbf{2}}$ upon trapping of ROS in HeLa cells in the absence (upper panels) and presence of $10 \mu \mathrm{M}$ rotenone (lower panels), 0 and $100 \mathrm{sec}$ after addition of the inhibitor as well as the time course of these changes (bottom panel). 


\subsection{Detailed studies with $p$-nitrostilbene-tert-butyl-nitrone, $\underline{1}$}

Spin-trapping of mainly superoxide anion radicals formed in mitochondria under various conditions was followed in HeLa cells as previously (Hauck et al., 2009) and as well for better comparison with data employing 2. Fig. 9 shows the fluorescence decay after $100 \mathrm{sec}$ in the absence of any inhibitor. All subsequent data are based on this control (Figs. 10 - 15). Results are summarized in Fig. 16.

The inhibitors of complexes I, rotenone, and complex III, antimycin A, have the strongest effect, particularly in combination. $\mathrm{KCN}$ is known to inhibit complex IV (Leavesley et al., 2010) and oligomycin blocks ATP synthesis by binding to the oligomycin sensitivity conferring protein, OSCP, of the $\mathrm{F}_{0}$ moiety of $\mathrm{F}_{1} \mathrm{~F}_{0}$-ATP synthase (Xu et al., 2000). The latter leads to an increased membrane potential and drives the respiratory chain backwards. In the absence of sufficient substrates for NADH this is known to produce superoxide anion radicals in complex I as in complex III via reaction of oxygen with the coenzyme $Q$ semiquinone radical (Muller et al., 2004).

Rather interesting is the effect of the protonophore CCCP (carbonyl-cyanide m-chlorophenyl hydrazone) which reduces the membrane potential (Nieminen et al., 1994) and thus, apparently also reduces ROS formation. The half-life of the fluorescence in its presence is almost doubled as compared to the control corroborating the opposite effect of oligomycin.
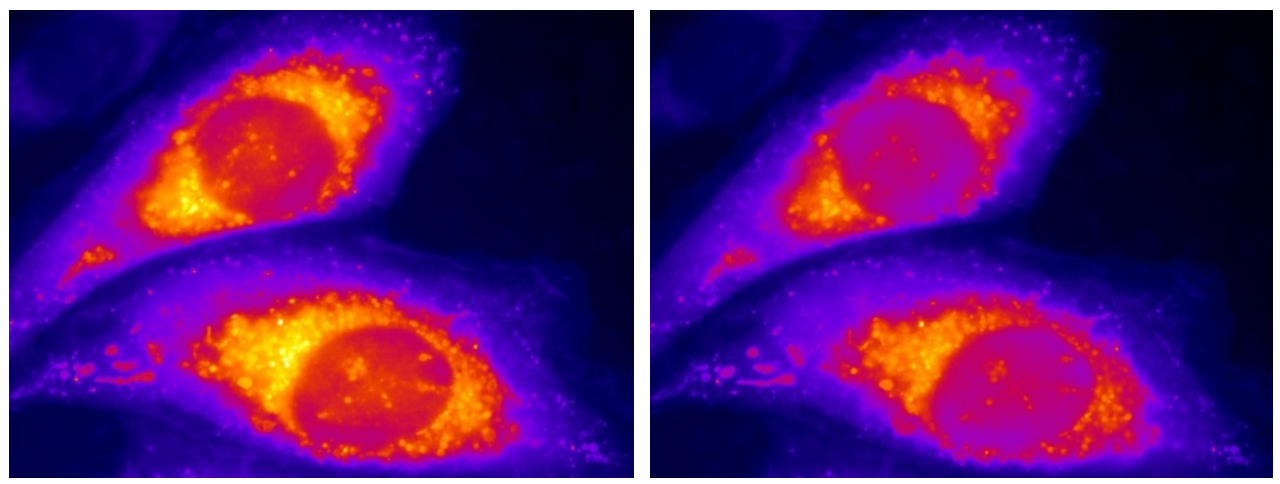

Figure 9. Fluorescence decay of $\underline{\mathbf{1}}$ in HeLa cells within $100 \mathrm{sec}$ in the absence of any inhibitor of respiration

\subsection{4-Pyrrolidine-1,8-naphthylimido-methylphenyl-tert-butyl-nitrone, $\underline{3}$}

In order to allow for excitation at longer wavelengths a third compound was synthesized according to the scheme in Fig. 17, again a tert-butyl-nitrone, but with 4-pyrrolidine-1,8naphthylimido-benzylidene as fluorescent moiety. 4-(1,3-Dioxacyclopent-2-yl)benzonitrile B was synthesized according to Ouari et al., 1998 in good yield and in the last step the formation of the nitrone $\underline{\mathbf{3}}$ was carried out according to Kim et al., 2007. 

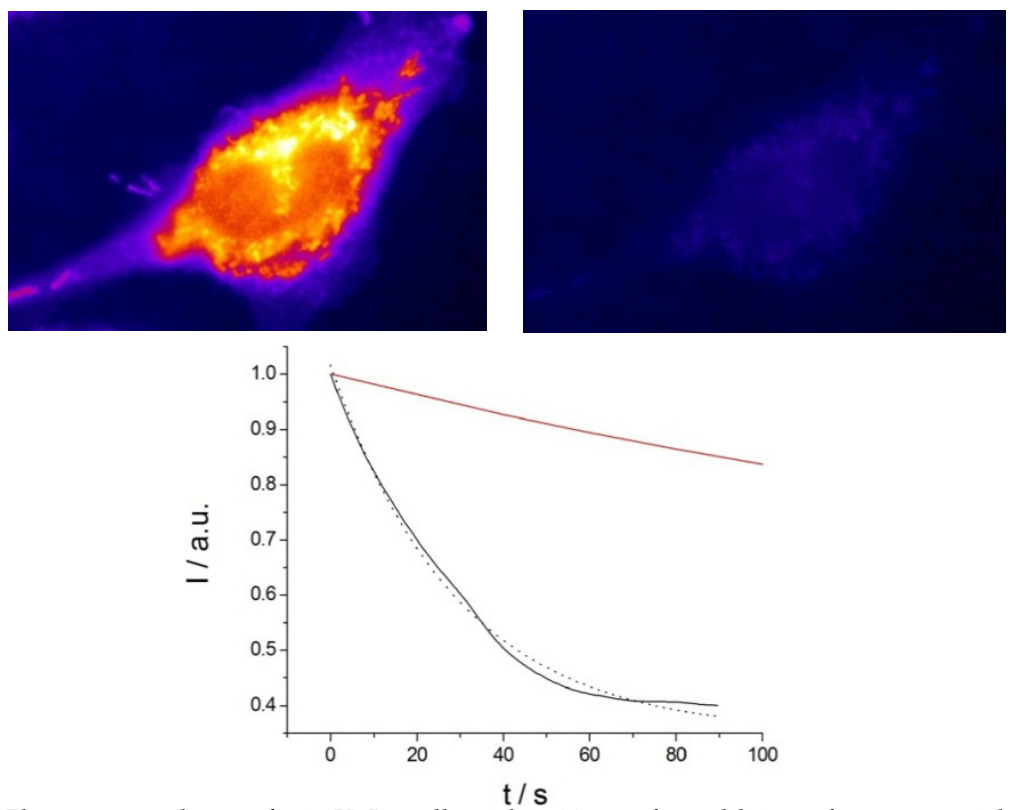

Figure 10. Fluorescence decay of $\underline{\mathbf{1}}$ in HeLa cells within $90 \mathrm{sec}$ after addition of rotenone with $\mathrm{t}_{1 / 2}=32$ sec, control $176 \mathrm{sec}$ assuming exponential decay (dotted lines)
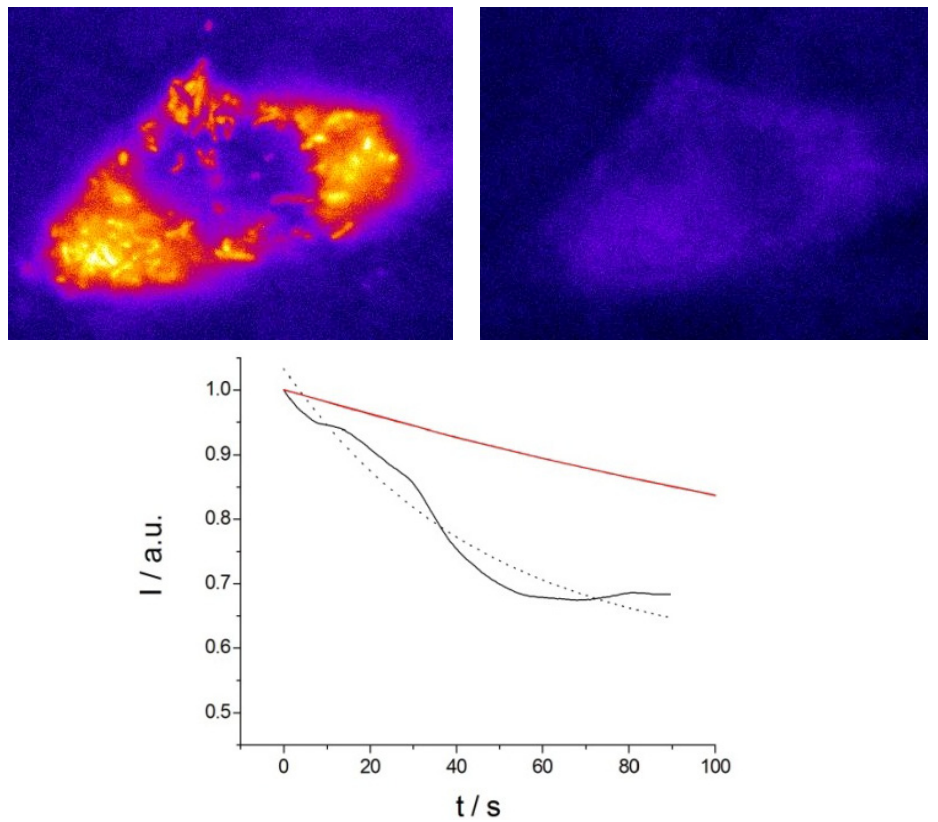

Figure 11. Fluorescence decay of $\underline{\mathbf{1}}$ in HeLa cells within $90 \mathrm{sec}$ after addition of antimycin A with $\mathrm{t}_{1 / 2}=20$ sec, control $176 \mathrm{sec}$ assuming exponential decay (dotted lines) 

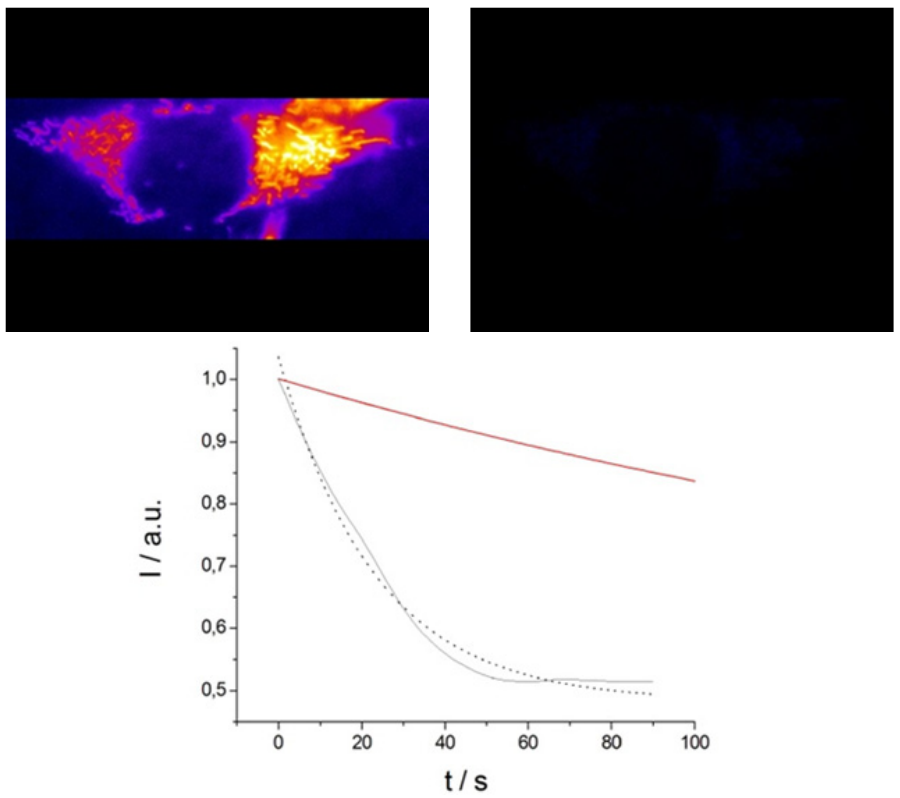

Figure 12. Fluorescence decay of $\underline{1}$ in HeLa cells within $90 \mathrm{sec}$ after addition of rotenone and antimycin A with $\mathrm{t}_{1 / 2}=16 \mathrm{sec}$, control $176 \mathrm{sec}$ assuming exponential decay (dotted lines)
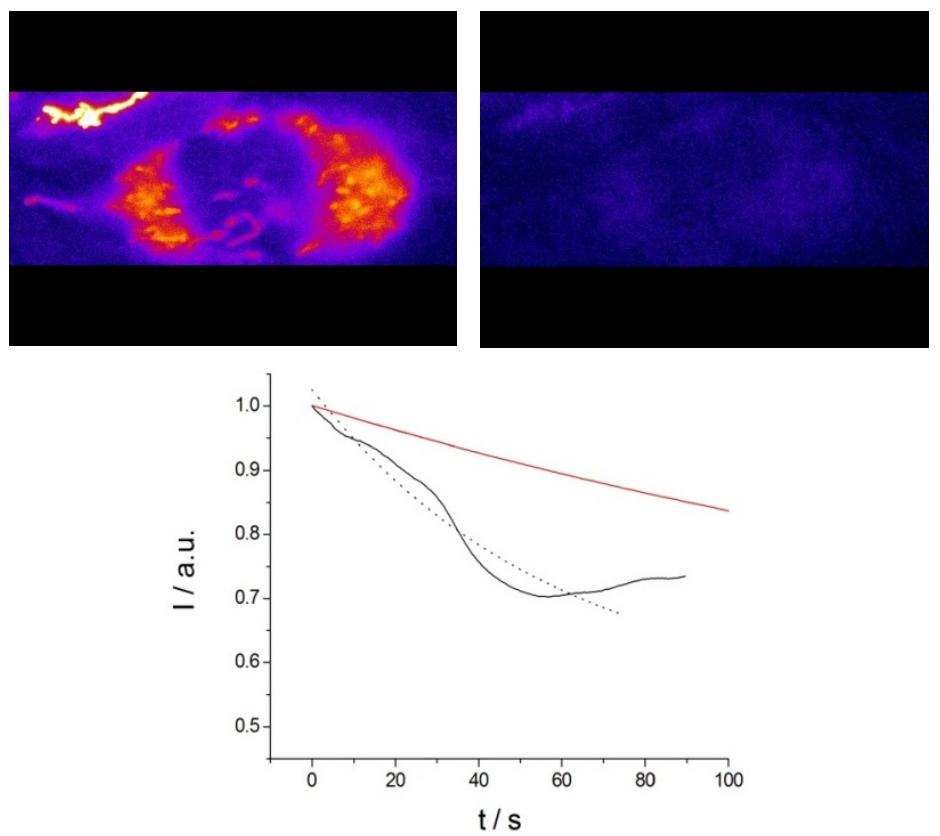

Figure 13. Fluorescence decay of $\underline{\mathbf{1}}$ in HeLa cells within $90 \mathrm{sec}$ after addition $\mathrm{KCN}$ with $\mathrm{t} / 2=40 \mathrm{sec}$, control $176 \mathrm{sec}$ assuming exponential decay (dotted lines) 

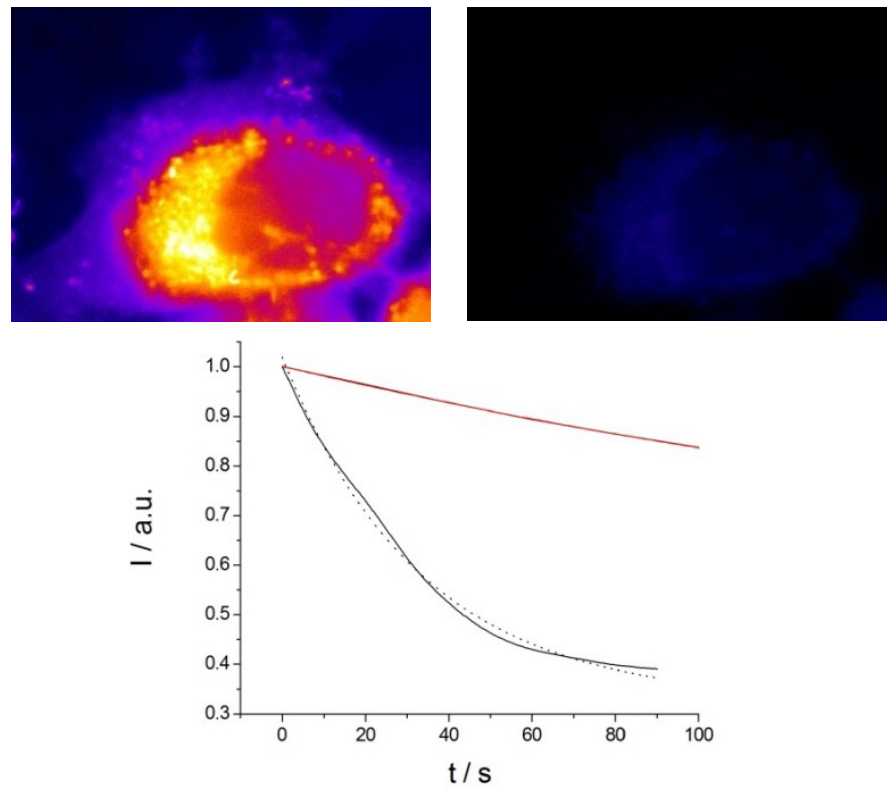

Figure 14. Fluorescence decay of $\underline{1}$ in HeLa cells within $90 \mathrm{sec}$ after addition of oligomycin with $t / 2=23$ sec, control 176 sec assuming exponential decay (dotted lines)
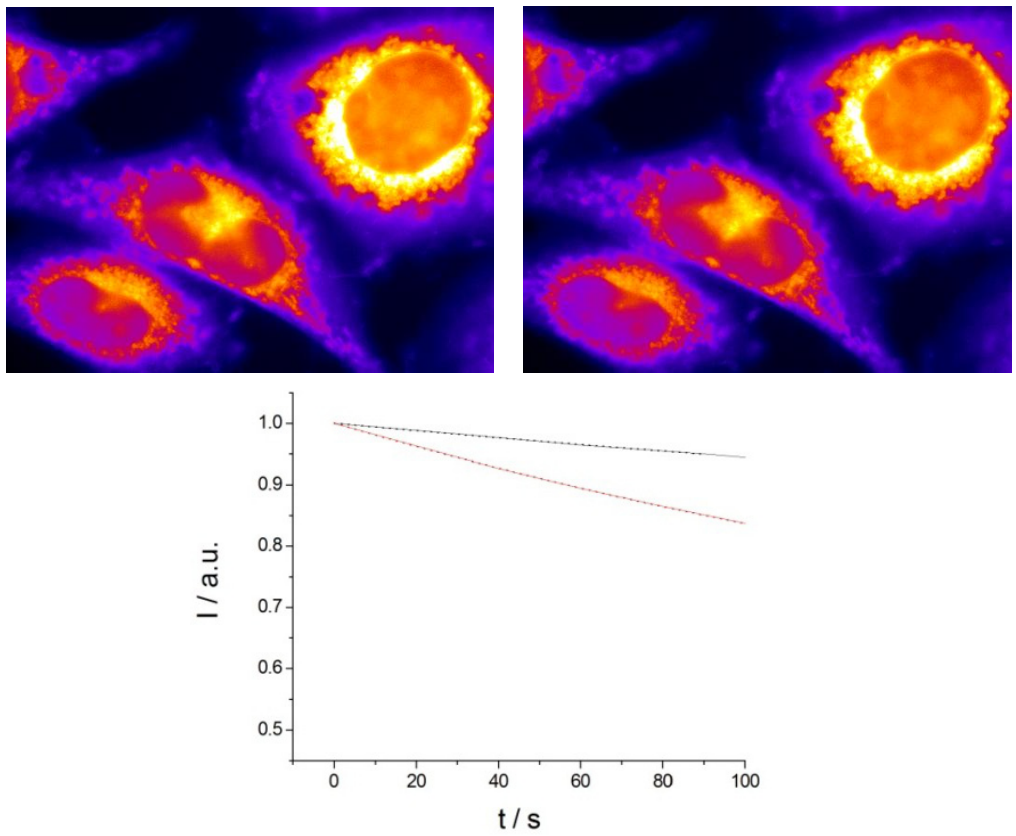

Figure 15. Fluorescence decay of $\underline{\mathbf{1}}$ in HeLa cells within $90 \mathrm{sec}$ in the presence of CCCP with $\mathrm{t} / 2=336$ sec, control $176 \mathrm{sec}$ (red) assuming exponential decay (dotted lines) 

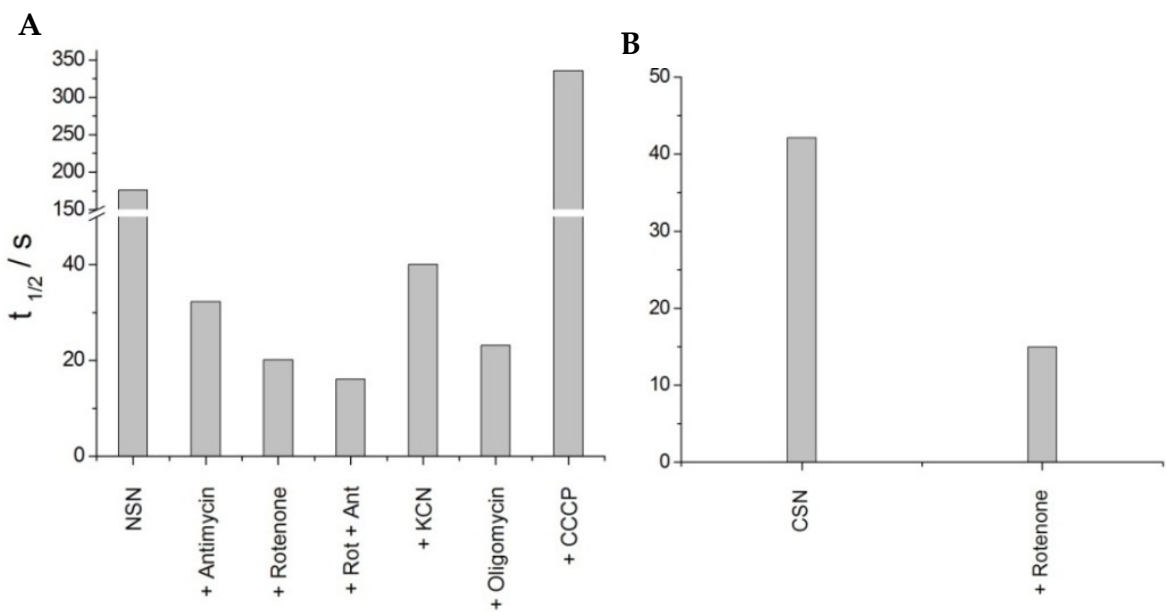

Figure 16. Effect of inhibitors of mitochondrial respiration on ROS formation as monitored by $\underline{\mathbf{1}}(\mathbf{A})$ and $\underline{2}(B)$
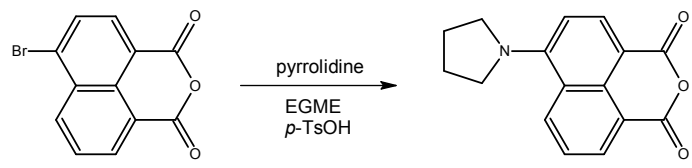

A
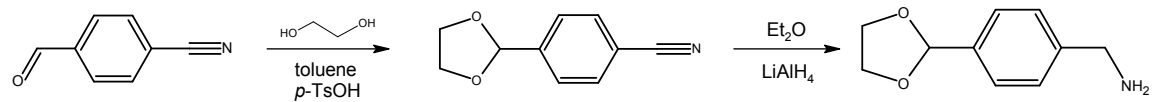

B
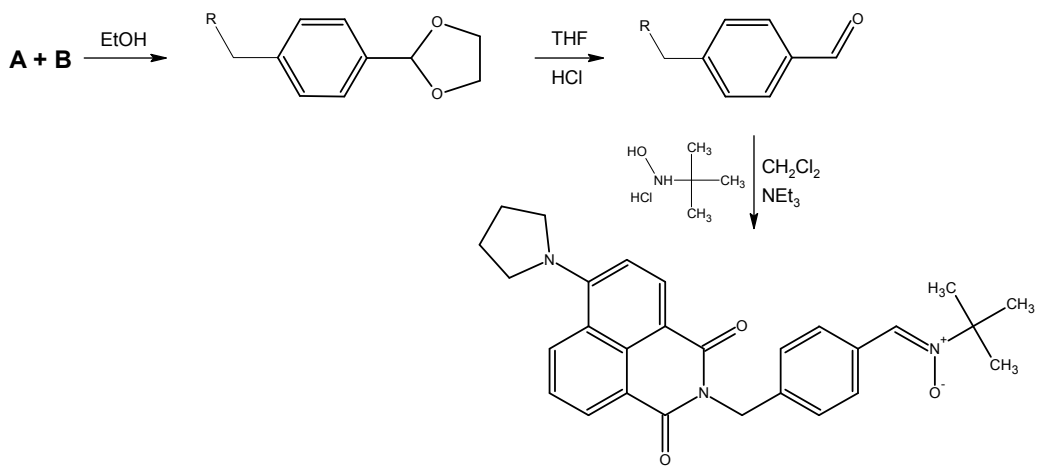

3

Figure 17. Synthetic scheme for the synthesis of 4-pyrrolidine-1,8-naphthylimido-methylphenyl-tertbutyl-nitrone, $\underline{3}$ 
Absorbance and fluorescence emission spectra are shown in Fig. 18. Fig. 18 A shows the fluorescence spectrum (red) with a maximum at $522 \mathrm{~nm}$ upon excitation at $488 \mathrm{~nm}$ and the UV/VIS spectrum with a maximum at $457 \mathrm{~nm}$ (black). Fig. $18 \mathrm{~B}$ illustrates the fluorescence spectrum (red) with a maximum at $514 \mathrm{~nm}$ upon excitation at $405 \mathrm{~nm}$. Excitation at $488 \mathrm{~nm}$ is well in the range of standard confocal laser microscopes and certainly, not likely to lead to radiation damage in biological systems. Within the concentration range feasible due to limitations in solubility, $\underline{\mathbf{3}}$ was non-toxic as studied so far in MCF-7 cells up to $5 \mu \mathrm{M}$ (data not shown).
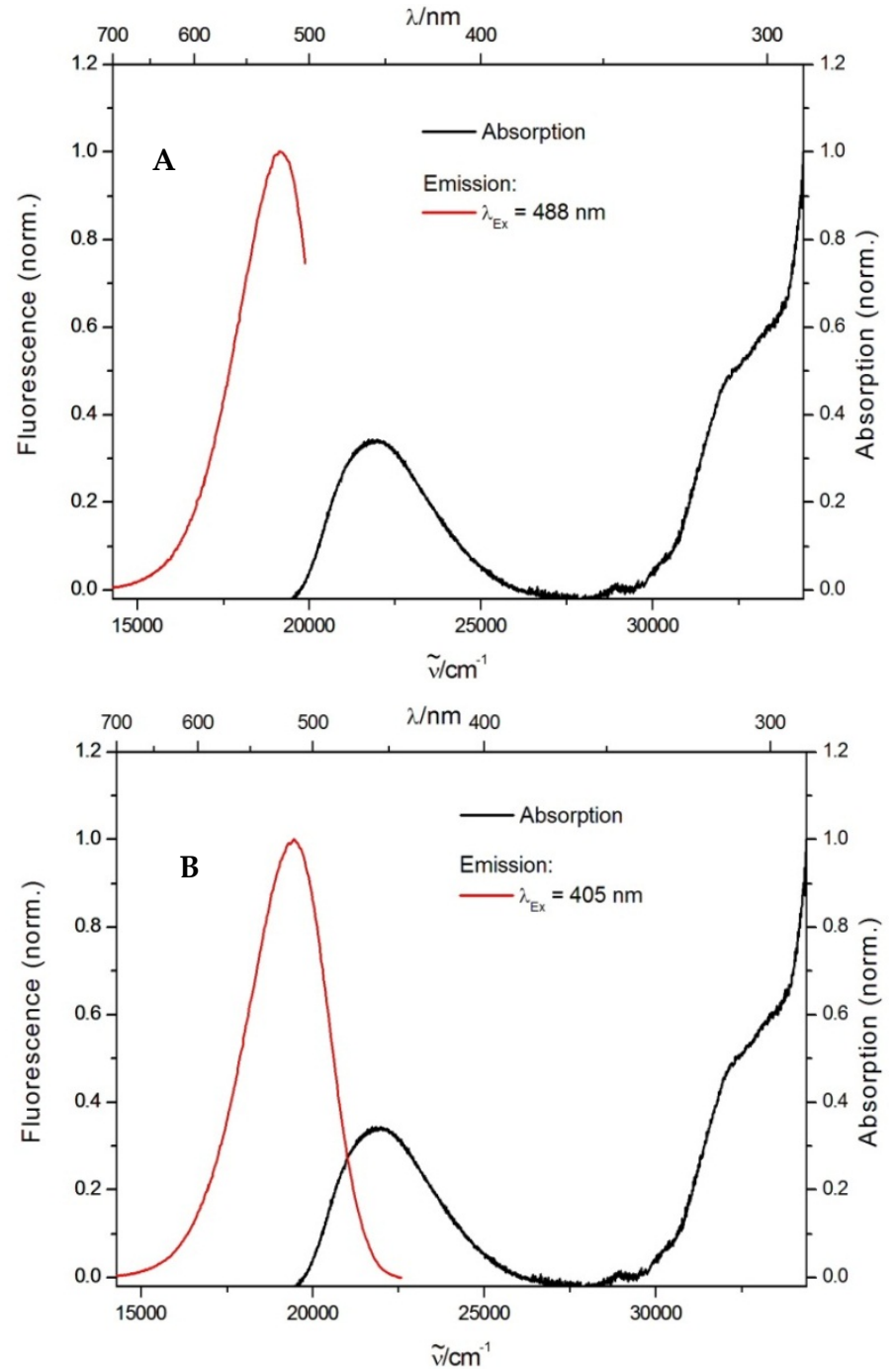

Figure 18. Absorption and fluorescence emission spectra of $\underline{3}$. Excitation at $488 \mathrm{~nm}$ (A) or $405 \mathrm{~nm}$ (B), respectively 
Preliminary spin trapping experiments with 3 were carried out with a regular confocal microscope with excitation at $488 \mathrm{~nm}$. Fig. 19 shows the control in the absence of inhibitors. As found before, complete quench occurs in about half an hour. Although the dye may accumulate again in mitochondria, we have not yet looked for co-localization with TMRE. Strikingly different are the effects of inhibitors as shown for antimycin A in Fig. 20. Corresponding experiments employing rotenone or both, rotenone and antimycin A as well as the Fenton reaction gave very similar results (data not shown). Quench is almost instantaneous,
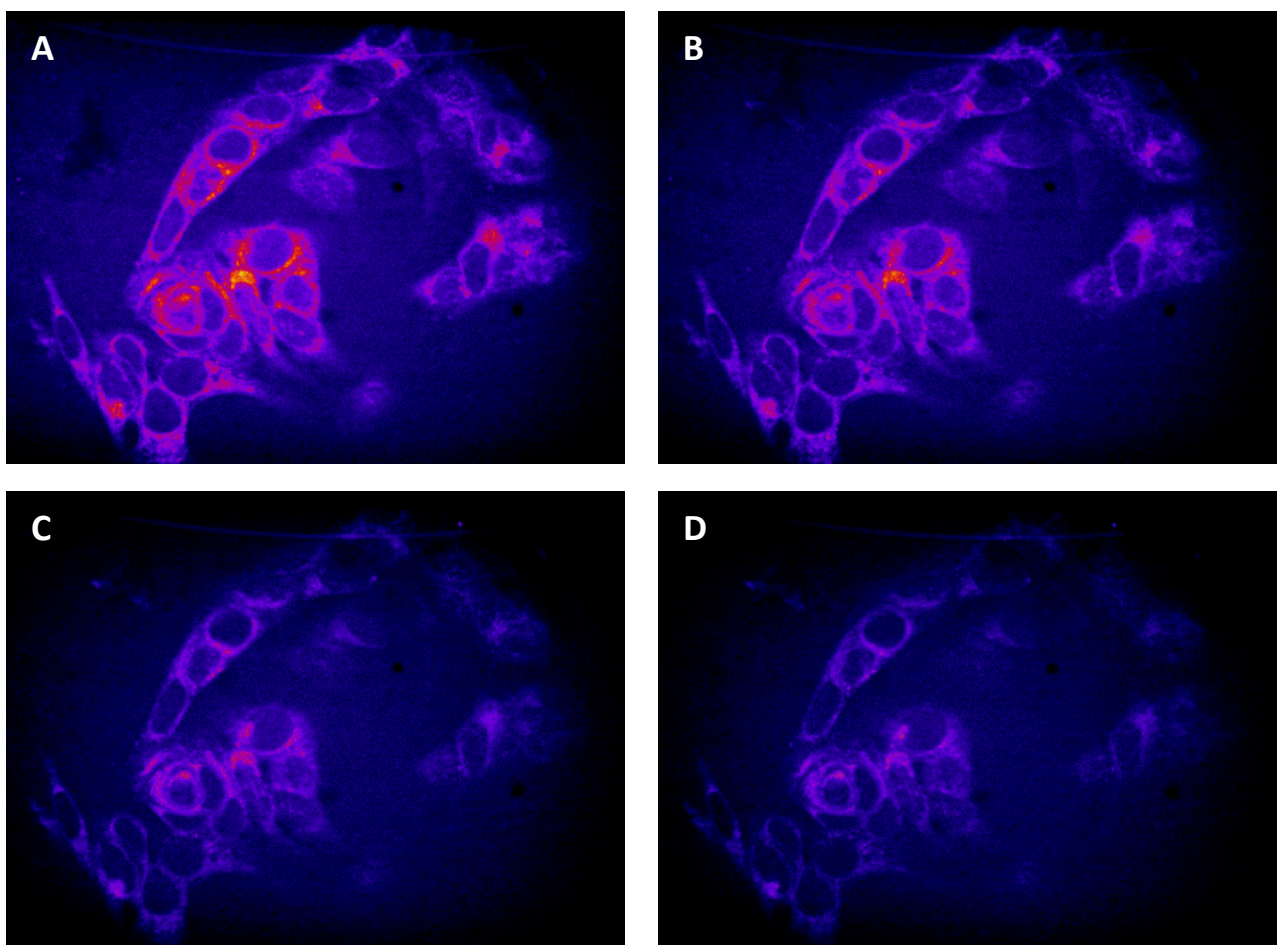

$\mathbf{E}$

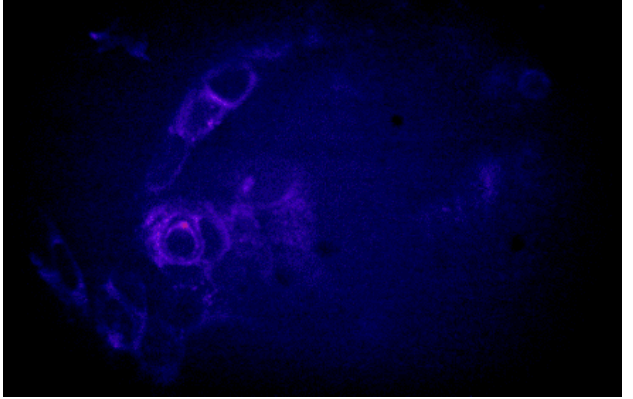

Figure 19. Fluorescence decay of $\underline{3}(1 \mu \mathrm{M})$ at selected times in MCF-7 cells: A: $0 \mathrm{~min}, \mathbf{B}: 5 \mathrm{~min}, \mathrm{C}: 10$ min, D: $15 \mathrm{~min}, \mathrm{E}: 20 \mathrm{~min}$ in the absence of inhibitors (control; laser intensity $80 \%$ and exposure $800 \mathrm{~ms}$ ) 
but fluorescence recovered within four to five seconds and then decayed completely over the next $15 \mathrm{~min}$. What could cause fluorescence recovery? The half-life of nitroxides as Tempone or Tempamine in viable systems is in the order of $30 \mathrm{~min}$ at most due to the reducing milieu in the cell (Berliner, 1991). Hence, the fluorescence being quenched by the radical could come back. There is however, also the possibility that differences are due to the experimental setup, i.e., a continuous flow device for the medium at the ApoTome to which the inhibitor was added, whereas in these experiments a concentrated solution of antimycin A etc. was manually injected directly into the medium surrounding the adherent cells.
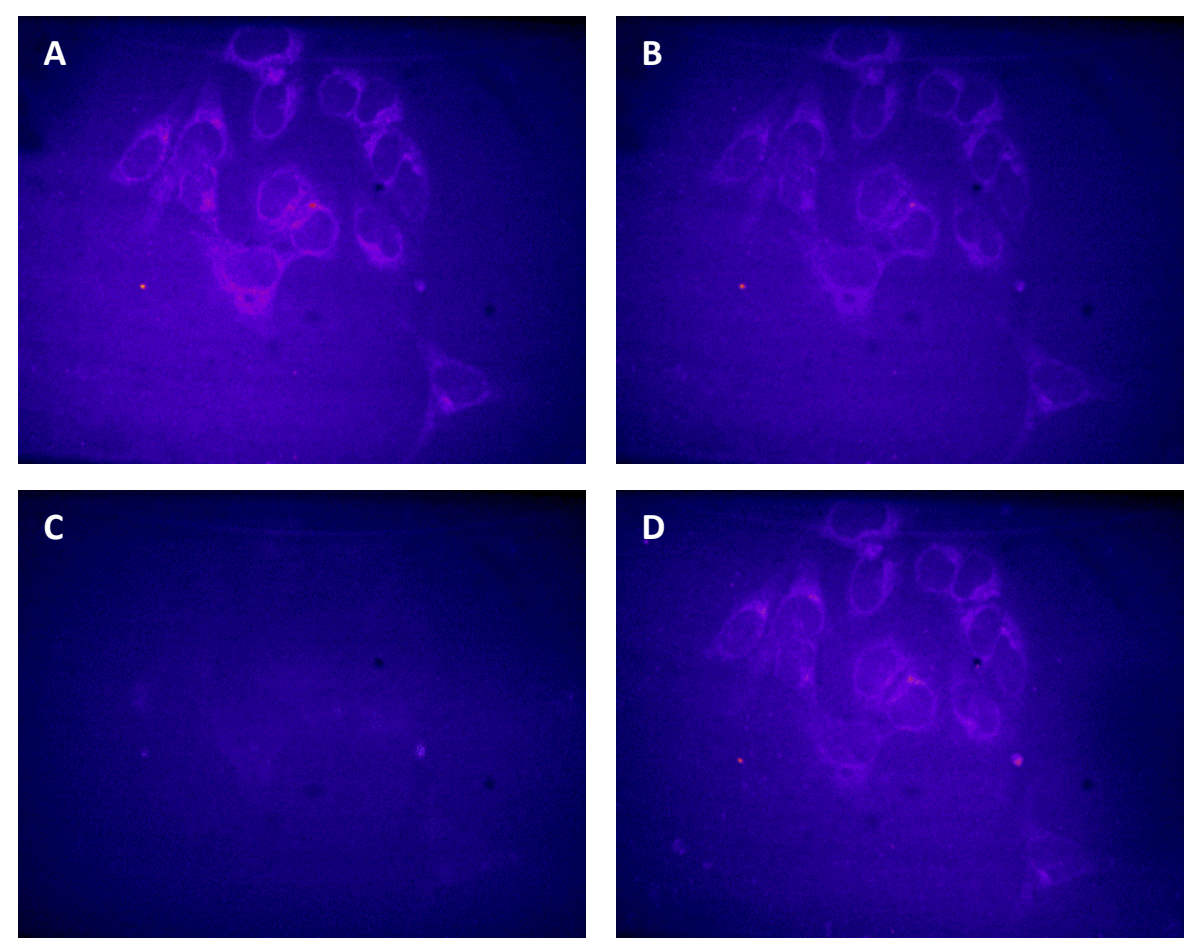

$\mathbf{E}$

Figure 20. Fluorescence decay of $\underline{3}$ in MCF-7 cells at selected times after addition of $1 \mu \mathrm{l}$ antimycin A (2 $\mathrm{mg} / \mathrm{ml}$ ) A: $0 \mathrm{sec}, \mathbf{B}: 1 \mathrm{sec}, \mathbf{C}: 2 \mathrm{sec}, \mathbf{D}: 4 \mathrm{sec}, \mathbf{E}: 13 \mathrm{~min}$ (laser intensity $80 \%$ and exposure $800 \mathrm{~ms}$ ) 


\section{Materials and methods}

\subsection{Synthesis of fluorescent nitrones}

\subsection{1. p-Nitrostilbene-tert-butyl-nitrone was synthesized as previously described (Hauck et} al., 2009).

\subsubsection{Coumaryl-styryl-tert-butyl-nitrone}

2-(4-Trifluoromethyl-2-oxo-2H-chromen-7-yl)-E-vinyl-1-(N-(1,1-dimethyl))-phenyl-4-nitrone was synthesized according to the scheme in Fig. 4.

\section{(Trifluoromethyl)-2-oxo-2H-chromene-7-diazoniumtetrafluoroborate}

To a solution of $2.62 \mathrm{mmol}$ of commercially available 7-amino-4-(trifluoromethyl)-coumarin (coumarin 151, Sigma-Aldrich, Taufkirchen, Germany) in $18 \mathrm{ml}$ of hydrochloric acid (18\%), a solution of sodium nitrite $(2.72 \mathrm{mmol})$ was added dropwise and stirred for $1 \mathrm{~h}$ at $0{ }^{\circ} \mathrm{C}$. Then, $41 \mathrm{mmol}$ tetrafluoroboric acid was added dropwise over $1 \mathrm{~h}$, with maintaining the reaction temperature lower than $0{ }^{\circ} \mathrm{C}$. (Trifluoromethyl)-2-oxo-2H-chromene-7-diazoniumtetrafluoroborate (1.52 mmol, yield: $58 \%$ ) was separated and rinsed with cold water, methanol and ethyl acetate. ${ }^{1} \mathrm{H}$-NMR: $6.45(\mathrm{~s}, 1 \mathrm{H}), 6.51(\mathrm{~d}, 1 \mathrm{H}, 2.4 \mathrm{~Hz}), 6.66(\mathrm{dd}, 1 \mathrm{H}, 8.8 \mathrm{~Hz}$ and $2.0 \mathrm{~Hz}), 7.37(\mathrm{dd}, 1 \mathrm{H}, 8.8 \mathrm{~Hz}$ and $2.0 \mathrm{~Hz})$.

\section{4-Bromobenzaldehyde-dimethyl-acetal}

4-Bromobenzaldehyde $(94.9 \mathrm{mmol})$ was dissolved in $120 \mathrm{ml}$ of dry methanol under an argon atmosphere, $96 \mu \mathrm{l}$ titanium chloride was added and the solution stirred for 20 minutes. After addition of $240 \mu \mathrm{l}$ trietylamine and 15 minutes of stirring, water was added and the product was extracted with diethyl ether. The organic phase was dried and the acetal isolated by evaporation of the solvent.

\section{[2-(4-Dimethoxymethylphenyl)-vinyl]-trimethyl-silane}

4-Bromobenzaldehyde-dimethyl-acetal (20.6 mmol) was dissolved in $20 \mathrm{ml}$ of dry acetonitrile under an argon atmosphere. The solution was boiled under reflux for $24 \mathrm{~h}$ after addition of $51.6 \mathrm{mmol}$ tetrabutylammonium acetate, $4 \%$ (by mol) palladium(II) acetate and $41.3 \mathrm{mmol}$ trimetyl-vinyl-silane. Then, $50 \mathrm{ml}$ PBS buffer $(\mathrm{pH}=7.4)$ was added and the product was extracted with diethyl ether. The organic phase was dried and the solvent removed by evaporation. The product was formed in $86 \%$ yield $(17.8 \mathrm{mmol}) .{ }^{1} \mathrm{H}$-NMR: 0.18 (s, 9H), 3.34 (s, 1H), 5.42 (s, 1H), 6.53 (d, 1 H, $19.07 \mathrm{~Hz}), 6.91$ (d, 1H, $19.41 \mathrm{~Hz}), 7.45(\mathrm{~m}, 2 \mathrm{H})$.

\section{(4-Trifluoromethyl-2-oxo-2H-chromen-7-yl)-E-2-vinyl]-benzaldehyde}

$2 \mathrm{mmol}$ (Trifluoromethyl)-2-oxo-2H-chromene-7-diazoniumtetrafluoroborate and $2 \mathrm{mmol}$ [2(4-dimethoxymethylphenyl)-vinyl]-trimethyl-silane were dissolved in $40 \mathrm{ml}$ of dry methanol and stirred for $5 \mathrm{~h}$ with $2 \%$ (by mol) palladium(II) acetate (Hiyama reaction). Water was added and the product was extracted with diethyl ether. The solvent was removed under vacuum and the product was washed with ethyl acetate. ${ }^{1} H$-NMR: $7.28(\mathrm{~s}, 2 \mathrm{H}), 7.33(\mathrm{~s}, 1 \mathrm{H})$, $7.72(\mathrm{t}, 2 \mathrm{H}, 8.86 \mathrm{~Hz}), 7.94(\mathrm{~d}, 2 \mathrm{H}, 8.51), 8.28(\mathrm{~d}, 1 \mathrm{H}, 8.86), 8.45(\mathrm{~d}, 1 \mathrm{H}, 8.51), 10.05(\mathrm{~s}, 1 \mathrm{H})$. 


\section{2-(4-Trifluoromethyl-2-oxo-2H-chromen-7-yl)-E-vinyl-1-(N-(1,1-dimethylethyl))-phenyl-4-nitrone $(\underline{2}, \mathrm{CSN})$}

$1.25 \mathrm{mmol}$ 4-[(4-Trifluoromethyl-2-oxo-2H-chromen-7-yl)-E-2-vinyl]-benzaldehyde and 1.85 mmol $N$-tert-butylhydroxylamine hydrochloride were dissolved in benzene and $\mathrm{p}$ toluenesulfonic acid was added as catalyst. The solution was boiled in a Dean-Stark apparatus (reflux and water removal) for $12 \mathrm{~h}$. Water was added and the product was extracted with ethyl acetate. ${ }^{1} H$-NMR: $1.66(\mathrm{~s}, 1 \mathrm{H}), 6.78(\mathrm{~s}, 1 \mathrm{H}), 7.22(\mathrm{~d}, 1 \mathrm{H}, 16.04 \mathrm{~Hz}), 7.28(\mathrm{~s}$, $1 \mathrm{H}), 7.30(\mathrm{~d}, 1 \mathrm{H}, 16.04 \mathrm{~Hz}), 7.63(\mathrm{~d}, 3 \mathrm{H}, 8.61 \mathrm{~Hz}), 7.73(\mathrm{t}, 2 \mathrm{H}, 8.61 \mathrm{~Hz}), 8.20$ (d, 1H, $8.61 \mathrm{~Hz})$, $8.35(\mathrm{~d}, 2 \mathrm{H}, 8.60 \mathrm{~Hz})$.

\subsubsection{4-Pyrrolidine-1,8-naphthylimido-methylphenyl-tert-butyl-nitrone, $\underline{3}$}

4-Pyrrolidine-1,8-naphthylimido-methylphenyl-tert-butyl-nitrone was synthesized according to the scheme in Fig. 17.

6-(Pyrrolidin-1-yl)-benzo[de]isochromene-1,3-dione

To a solution of $37.4 \mathrm{mmol}$ of commercially available 6-bromo-benzo[de]isochromene-1,3dione (Sigma-Aldrich, Taufkirchen, Germany) in $50 \mathrm{ml}$ of methyl glycol was added 56.7 mmol pyrrolidine and a catalytic amount of $p$-toluenesulfonic acid and was boiled under reflux for $6 \mathrm{~h}$. After cooling to $0{ }^{\circ} \mathrm{C}$ the precipitation was filtered off and washed with cold ethanol. The crude product was recrystallized from n-hexane and dried. 6-(Pyrrolidin-1-yl)benzo[de]isochromene-1,3-dione was formed in $90 \%$ yield $(33.7 \mathrm{mmol}) . \mathrm{C}_{16} \mathrm{H}_{13} \mathrm{NO}_{3}(267.3$ g/mol) calc.: C, $71.90 \%$; H, $4.90 \%$; N, $5.24 \%$. found: C, $71.76 \%$;, 4.88 \%; N, $5.23 \%$. Mp.: $284{ }^{\circ} \mathrm{C} .{ }^{1} \mathrm{H}$-NMR (chloroform-d, $\left.400 \mathrm{MHz}\right): \delta[\mathrm{ppm}]=2.07-2.19(\mathrm{~m}, 4 \mathrm{H}), 3.75-3.89(\mathrm{~m}, 4$ $\mathrm{H}), 6.77(\mathrm{~d}, 1 \mathrm{H}, 8.81 \mathrm{~Hz}), 7.52(\mathrm{t}, 1 \mathrm{H}, 7.30 \mathrm{~Hz}), 8.31(\mathrm{~d}, 1 \mathrm{H}, 8.81 \mathrm{~Hz}), 8.50(\mathrm{~d}, 1 \mathrm{H}, 7.30 \mathrm{~Hz})$, $8.64(\mathrm{~d}, 1 \mathrm{H}, 8.81 \mathrm{~Hz}) .{ }^{13} \mathrm{C}\left\{{ }^{1} \mathrm{H}\right\}-\mathrm{NMR}$ (chloroform-d, $\left.100 \mathrm{MHz}\right): \delta[\mathrm{ppm}]=160.9,153.2,135.4$, 134.0, 133.4, 133.0, 123.2, 122.3, 118.6, 108.8, 53.3, 26.1 .

\section{4-(1,3-Dioxacyclopent-2-yl)-benzonitrile}

To a solution of $79.5 \mathrm{mmol}$ of commercially available 4-cyanobenzaldehyde (Merck, Darmstadt, Germany) in $150 \mathrm{ml}$ toluene, was added $0.32 \mathrm{~mol}$ of ethylene glycol and $p$ toluenesulfonic acid was added as catalyst. The solution was boiled in a Dean-Stark apparatus for $20 \mathrm{~h}$. After complete removal of water, the solution was stirred for $20 \mathrm{~h}$ at room temperature. Then, $60 \mathrm{ml}$ of a $5 \%$ sodium bicarbonate aqueous solution was added. The organic layer was washed three times with $25 \mathrm{ml}$ bidest. water each and dried over magnesium sulfate. The solvent was removed under vacuum and the remaining colorless liquid was crystallized from n-hexane and dried under reduced pressure. The hygroscopic product was formed in $95 \%$ yield $(75.9 \mathrm{mmol}) . \mathrm{C}_{10} \mathrm{H}_{9} \mathrm{NO}_{2}(175.2 \mathrm{~g} / \mathrm{mol})$ calc.: $\mathrm{C}, 68.56 \%$; $\mathrm{H}$, $5.18 \%$; N, $8.00 \%$. found: C, $68.58 \%$; H, $5.12 \%$; N, $8.09 \%$. Mp.: -. ${ }^{1} \mathrm{H}$-NMR (chloroform-d, $400 \mathrm{MHz}): \delta[\mathrm{ppm}]=4.02-4.11(\mathrm{~m}, 4 \mathrm{H}), 5.83(\mathrm{~s}, 1 \mathrm{H}), 7.58(\mathrm{~d}, 2 \mathrm{H}, 8.56 \mathrm{~Hz}), 7.66(\mathrm{~d}, 2 \mathrm{H}, 8.06$ $\mathrm{Hz}) .{ }^{13} \mathrm{C}\left\{{ }^{1} \mathrm{H}\right\}-\mathrm{NMR}$ (chloroform-d, $100 \mathrm{MHz}$ ): $\delta[\mathrm{ppm}]=143.1,132.2,127.2,118.6,112.9,102.4$, 65.4 . 


\section{4-(1,3-Dioxolan-2-yl)-phenylmethanamine}

4-(1,3-Dioxolan-2-yl)-benzonitrile $(42.2 \mathrm{mmol})$ was dissolved in $50 \mathrm{ml}$ of dry diethyl ether under an argon atmosphere and was added dropwise at $0{ }^{\circ} \mathrm{C}$ to a well-stirred suspension of $\mathrm{LiAlH}_{4}(84.5 \mathrm{mmol})$ in $100 \mathrm{ml}$ of dry diethyl ether. The suspension was stirred at this temperature for $4 \mathrm{~h}$, then the mixture was allowed to warm up to room temperature and was stirred for a further $18 \mathrm{~h}$. Afterwards, the mixture was hydrolyzed by $35 \mathrm{ml}$ of $95 \%$ ethanol and then by $35 \mathrm{ml}$ of $50 \%$ ethanol. The ether layer was separated and the aqueous phase lyophilized. The resulting solid was extracted with $80 \mathrm{ml}$ dichloromethane. The combined organic layers were dried over $\mathrm{MgSO}_{4}$ and the yellowish-white solid product was obtained by evaporation of the solvent and crystallized in the fridge in $94 \%$ yield $(39.5$ mmol). ${ }^{1} \mathrm{H}-\mathrm{NMR}$ (chloroform-d, $400 \mathrm{MHz}$ ): $\delta$ [ppm] = 1.49 (s, $\left.2 \mathrm{H}\right), 3.87$ (s, $\left.2 \mathrm{H}\right), 3.99-4.15$ (m, $4 \mathrm{H}), 5.80(\mathrm{~s}, 1 \mathrm{H}), 7.32(\mathrm{~d}, 2 \mathrm{H}, 8.19 \mathrm{~Hz}), 7.44(\mathrm{~d}, 2 \mathrm{H}, 8.19 \mathrm{~Hz}) .{ }^{13} \mathrm{C}\left\{{ }^{1} H\right\}-\mathrm{NMR}$ (chloroformd, $100 \mathrm{MHz}): \delta[\mathrm{ppm}]=144.4,136.4,127.1,126.7,103.6,65.3,46.3$.

\section{2-(4-(1,3-Dioxolan-2-yl)-benzyl)-6-(pyrrolidin-1-yl)-1H-benzo[de]isoquinoline-1,3(2H)-dione}

$7.11 \mathrm{mmol}$ of 6-pyrrolidin-1-yl)-benzo[de]isochromene-1,3-dione and $10.7 \mathrm{mmol}$ of 4-(1,3dioxolan-2-yl)-phenylmethanamine were dissolved in $130 \mathrm{ml}$ of ethanol. The mixture was boiled under reflux for $23 \mathrm{~h}$ and then cooled to $0{ }^{\circ} \mathrm{C}$. The resulting orange solid was filtered off and washed four times with $20 \mathrm{ml}$ of cold ethanol each. The crude product was recrystallized from toluene and dried over $\mathrm{MgSO}_{4}$. The product was obtained as an orange solid in $88 \%$ yield (6.26 mmol). $\mathrm{C}_{26} \mathrm{H}_{24} \mathrm{~N}_{2} \mathrm{O}_{4}(428.5 \mathrm{~g} / \mathrm{mol})$ calc.: C, $72.88 \%$; $\mathrm{H}, 5.65 \%$; N, 6.54 $\%$. found: C, $72.68 \%$; H, $5.70 \%$; N $6.36 \%$. Mp.: $189{ }^{\circ} \mathrm{C} .{ }^{1} \mathrm{H}-\mathrm{NMR}$ (chloroform-d, $400 \mathrm{MHz}$ ): $\delta$ $[\mathrm{ppm}]=2.05-2.12(\mathrm{~m}, 4 \mathrm{H}), 3.74-3.80(\mathrm{~m}, 4 \mathrm{H}), 3.95-4.09(\mathrm{~m}, 4 \mathrm{H}), 5.37(\mathrm{~s}, 2 \mathrm{H}), 5.78(\mathrm{~s}, 1$ $\mathrm{H}), 6.80(\mathrm{~d}, 1 \mathrm{H}, 8.61 \mathrm{~Hz}), 7.38$ (d, $2 \mathrm{H}, 7.83 \mathrm{~Hz}, 2 \mathrm{H}), 7.51$ (t, $1 \mathrm{H}, 8.61 \mathrm{~Hz}), 7.56$ (d, $2 \mathrm{H}, 8.22$ $\mathrm{Hz}), 8.41(\mathrm{~d}, 1 \mathrm{H}, 8.86 \mathrm{~Hz}), 8.56(\mathrm{t}, 2 \mathrm{H}, 5.09 \mathrm{~Hz}) .{ }^{13} \mathrm{C}\left\{{ }^{1} \mathrm{H}\right\}-\mathrm{NMR}$ (chloroform-d, $100 \mathrm{MHz}$ ): $\delta$ $[\mathrm{ppm}]=164.8,164.0,152.7,138.9,136.9,133.6,132.0,131.2,128.9,126.4,123.0,122.6,122.5$, $110.5,108.5,103.6,65.2,53.2,43.0,26.1$.

\section{4-((1,3-Dioxo-6-(pyrrolidin-1-yl)-1H-benzo[de]isoquinolin-2(3H)-yl)-methyl)-benzaldehyde}

To a solution of 2-(4-(1,3-dioxolan-2-yl)-benzyl)-6-(pyrrolidin-1-yl)-1H-benzo[de]isoquinoline1,3(2H)-dione $(8.40 \mathrm{mmol})$ in $100 \mathrm{ml} \mathrm{THF}$, was added $25 \mathrm{ml}$ of $3 \%$ hydrochloric acid. The solution was boiled under reflux for $4 \mathrm{~h}$ and then cooled to $0{ }^{\circ} \mathrm{C}$. Afterwards, the solution was brought to $\mathrm{pH} 8$ with triethylamine upon which an orange precipitate was formed. The crude product was filtered off, washed three times with $20 \mathrm{ml}$ of water each. The orange aldehyde was obtained in $98 \%$ yield $(8.22 \mathrm{mmol})$ and was stored under argon unless used immediately. $\mathrm{C}_{24} \mathrm{H}_{20} \mathrm{~N}_{2} \mathrm{O}_{3}(384.4 \mathrm{~g} / \mathrm{mol})$ calc.: C, $74.98 \%$; $\mathrm{H}, 5.24 \%$;, $7.29 \%$. found: $\mathrm{C}, 74.60$ \%; H, $5.27 \%$; N, $6.91 \%$. Mp.: $160{ }^{\circ} \mathrm{C} .{ }^{1} \mathrm{H}$-NMR (chloroform-d, $400 \mathrm{MHz}$ ): $\delta$ [ppm] = $2.05-$ $2.14(\mathrm{~m}, 4 \mathrm{H}), 3.74-3.84(\mathrm{~m}, 4 \mathrm{H}), 5.43(\mathrm{~s}, 2 \mathrm{H}), 6.81(\mathrm{~d}, 1 \mathrm{H}, 8.61 \mathrm{~Hz}), 7.53(\mathrm{t}, 1 \mathrm{H}, 7.43 \mathrm{~Hz})$, $7.65(\mathrm{~d}, 2 \mathrm{H}, 8.22 \mathrm{~Hz}), 7.80(\mathrm{~d}, 2 \mathrm{H}, 8.22 \mathrm{~Hz}), 8.43(\mathrm{~d}, 1 \mathrm{H}, 8.61 \mathrm{~Hz}), 8.60(\mathrm{t}, 2 \mathrm{H}, 7.43 \mathrm{~Hz}), 9.95$ (s, $1 \mathrm{H}) .{ }^{13} \mathrm{C}\left\{{ }^{1} H\right\}-\mathrm{NMR}$ (chloroform-d, $100 \mathrm{MHz}$ ): $\delta$ [ppm] = 192.0, 163.9, 152.9, 144.9, 135.4, 133.8, 132.3, 131.4, 129.9, 129.1, 126.4, 123.1, 122.6, 122.2, 108.6, 53.2, 43.2, 26.1. 
(Z)-N-(4-((1,3-dioxo-6-(pyrrolidin-1-yl)-1H-benzo[de]isoquinolin-2(3H)-yl-)methyl)-benzylidene)-2methylpropan-2-amine oxide

A suspension of 4-((1,3-dioxo-6-(pyrrolidin-1-yl)-1H-benzo[de]isoquinolin-2(3H)-yl)methyl)-benzaldehyde ( $3 \mathrm{mmol}), \mathrm{N}$-(tert-butyl)hydroxylamine hydrochloride $(6 \mathrm{mmol})$, triethylamine $(6.6 \mathrm{mmol})$ and sodium sulfate $(17.6 \mathrm{mmol})$ as desiccant in $50 \mathrm{ml} \mathrm{CH} 2 \mathrm{Cl}_{2}$ was stirred for 9 days at room temperature under argon. Afterwards, the mixture was filtered off and the solid was washed three times with $20 \mathrm{ml} \mathrm{CH}_{2} \mathrm{Cl}_{2}$ each. The organic layer was dried and the crude product isolated by evaporation of the solvent. Then, the orange solid was recrystallized from ethanol and the nitrone was purified by column chromatography (200400 mesh chromagel; solvent: methylene chloride/acetone/triethylamine, 12:1:0.1) in $38 \%$ yield (1.14 mmol). ${ }^{1} \mathrm{H}$-NMR (chloroform-d, $\left.400 \mathrm{MHz}\right): \delta[\mathrm{ppm}]=1.57(\mathrm{~s}, 9 \mathrm{H}), 2.07-2.10(\mathrm{~m}, 4$ $\mathrm{H}), 3.75-3.79(\mathrm{~m}, 4 \mathrm{H}), 5.37(\mathrm{~s}, 2 \mathrm{H}), 6.80(\mathrm{~d}, 1 \mathrm{H}, 8.80 \mathrm{~Hz}), 7.47(\mathrm{~s}, 1 \mathrm{H}), 7.51(\mathrm{dd}, 1 \mathrm{H}, 8.56$ $\mathrm{Hz}, 7.43 \mathrm{~Hz}), 7.56$ (d, $2 \mathrm{H}, 8.56 \mathrm{~Hz}, 2 \mathrm{H}), 8.19$ (d, $2 \mathrm{H}, 8.56 \mathrm{~Hz}), 8.41$ (d, $1 \mathrm{H}, 8.80 \mathrm{~Hz}), 8.57$ (m, $2 \mathrm{H}) .{ }^{13} \mathrm{C}\left\{{ }^{1} \mathrm{H}\right\}$-NMR (chloroform-d, $\left.100 \mathrm{MHz}\right): \delta$ [ppm] = 164.8, 164.0, 152.8, 140.0, 133.7, 132.1, 131.3, 130.0, 129.6, 128.8, 128.7, 123.0, 122.6, 122.5, 110.5, 108.5, 70.6, 53.1, 43.2, 28.3, 26.1.

\subsection{UV/VIS and fluorescence spectroscopy}

$500 \mu \mathrm{M}$ stock solutions of the spin traps in dimethyl sulfoxide containing $1 \% \mathrm{C}_{12} \mathrm{E} 9$ were employed. For fluorescence spectra the solutions were added to $25 \mathrm{mM}$ phosphate buffer, $\mathrm{pH}=7.2$, with $1 \%$ Triton-X 100 to a final concentration of $1 \mu \mathrm{M}$. To simulate photobleaching in the fluorescence microscope, the solutions were irradiated for three minutes with a blue LED light source $(\lambda=366 \mathrm{~nm})$ and compared to samples without prior irradiation.

\subsection{Cytotoxicity}

Cytotoxicity of the spin traps was determined by the sulforhodamine assay. $170 \mu \mathrm{l}$ of a cell suspension of 8000 cells $/ \mathrm{ml}$ of Hela or MCF-7 cells were added to $20 \mathrm{ml}$ of RPMI medium and $1 \mathrm{ml}$ each was pipetted into a 24 wells plate and incubated for $48 \mathrm{~h}$ at $37^{\circ} \mathrm{C}$ under $5 \%$ $\mathrm{CO}_{2}$. After this time, the cells were incubated for another $72 \mathrm{~h}$ with RPMI medium containing $0.5 \%$ DMSO and the spin trap at six concentrations varying from 0 to $200 \mu \mathrm{M}$. The reaction was stopped by addition of $100 \mu \mathrm{l}$ of $50 \%$ trichloroacetic acid for $1 \mathrm{~h}$ at $4{ }^{\circ} \mathrm{C}$ and subsequently washed four times with cold water and then dried for $24 \mathrm{~h}$ at room temperature followed by addition of $250 \mu \mathrm{l}$ of sulforhodamine B solution $(0.4 \%$ in $1 \%$ acetic acid; Sigma, Taufkirchen). After 30 min wells were washed three times with cold water and another three times with $1 \%$ acetic acid, dried for $24 \mathrm{~h}$ at room temperature and extinction measured at $570 \mathrm{~nm}$ after addition of $1 \mathrm{ml}$ of $10 \mathrm{mM}$ Tris base solution, $\mathrm{pH}$ 10.0.

In case of $\underline{3}$ concentrations were varied from 0 to $5 \mu \mathrm{M}$ in RPMI medium containing $0.5 \%$ DMSO and $0.5 \%$ ethanol in addition.

\subsection{Fluorescence microscopy measurements}

These were carried out using a quasi-confocal microscope (Axiovert 440 equipped with an ApoTome, Carl Zeiss, Jena) as previously described (Hauck et al., 2009). For corresponding 
measurements with $\underline{\mathbf{3}}$ a Nikon Eclipse E 600 confocal microscope equipped with a Hamamatsu ORCA-ER camera was employed. After 20 minutes of incubation with $1 \mu \mathrm{M}$ spin trap and $0.5 \%$ DMSO the cells were washed three times with RPMI medium and the coverslip was mounted on a chamber and put under the microscope. Imaging was achieved by laser excitation at $488 \mathrm{~nm}$.

To determine the half-life of fluorescence, a representative cell was defined as region of interest (ROI) and the evolution of average intensity of the ROI was investigated in the presence and absence of various inhibitors of components of mitochondrial proteins.

\section{Conclusions}

At the moment, the $p$-nitrostilbene-tert-butyl-nitrone $(\underline{\mathbf{1}})$ seems to be best suited for investigations of ROS formation in mitochondria. Unfortunately, the cytotoxicity of the coumaryl derivative (2) limits it application potential. The third molecule, 4-pyrrolidine-1,8naphthylimido-methylphenyl-tert-butyl-nitrone ( $\underline{3})$ still requires further detailed evaluation. If confirmed that it distributes fairly evenly throughout the cell it would nicely complement data from $\underline{1}$. With respect to the bioreduction leading to fluorescence recovery and timedependent changes in fluorescence, although reproducible, we still have to make sure that this was not due to an experimental artifact employing different instrumentation.

\section{Author details}

Stefan Hauck, Yvonne Lorat, Fabian Leinisch, Christian Kopp, Jessica Abrossinow and Wolfgang E. Trommer

Department of Chemistry, TU Kaiserslautern, Germany

\section{Acknowledgement}

The authors thank Anneken Grün and André Karbach, Kaiserslautern, for their help in the syntheses as well as Dr. Lars Kästner, University of the Saarland, Homburg, for assistance with confocal laser microscopy and Yvonne Schmitt, Kaiserslautern, with fluorescence spectroscopy.

\section{References}

Berliner, L.J. (1991). Applications of in vivo EPR. In: EPR Imaging and in vivo EPR. Eaton, G.R., Eaton, S.S. \& Ohno, Keiichi, eds. pp. 291-310. CRC Press, Boca Raton, FL, USA

Blough, N.V. \& Simpson, D.J. (1988). Chemically mediated fluorescence yield switching in nitroxide-fluorophore adducts: optical sensors of radical/redox reactions. J. Amer. Chem. Soc. 110, 1915-1917

Bottle, S.E., Hanson, G.R. \& Micallef, A.S. (2003). Application of the new EPR spin trap 1,1,3trimethylisoindole N-oxide (TMINO) in trapping $\mathrm{OH} \cdot$ and related biologically important radicals. Org. Biomol. Chem. 1, 2585-2589 
Boveris, A. (1977). Mitochondrial production o superoxide radical and hydrogen peroxide. Adv. Exp. Med. Biol. 78, 67-82

Bystryak, I.M., Likhtenshtein, G.I., Kotel'nikov, A.I., Hankovsky, O. \& Hideg, K. (1986). The influence of the molecular dynamics of the solvent on the photoreduction of nitroxy radicals. Russian J. Phys. Chem. 60, 1679-1683

Cadenas, E. \& Davies, K.J.A. (2000). Mitochondrial free radical generation, oxidative stress and aging. Free Radical Biol. Med. 29, 222-230

Dlaskova, A., Hlavata, L. \& Jezek, P. (2008). Oxidative stress caused by blocking of mitochondrial complex $\mathrm{I} \mathrm{H}^{(+)}$pumping as link in aging/disease vicious cycle. Int. J. Biochem. E Cell Biol. 40, 1792-1805

Dröge, W. (2002). Free radicals in the physiological control of cell function. Physiological Rev. $82,47-95$

Farkas, D.L., Wei, M.D., Febbroriello, P., Carson, J.H. \& Loew, L.M. (1989). Simultaneous imaging of cell and mitochondrial membrane potentials . Biophys. J. 56, 1053-1069

Han, D., Williams, E. \& Cadenas, E. (2001). Mitochondrial respiratory chain-dependent generation of superoxide anion and its release into the intermembrane space. Biochem. J. 353, 411-416

Hauck, S., Lorat, Y., Leinisch, F. \& Trommer, W.E. (2009). p-Nitrostilbene-t-butyl-nitrone: a novel fluorescent spin trap for the detection of ROS with subcellular resolution. Appl. Magn. Reson. 36, 133-147

Heyne, B., Beddie, C. \& Scaiano, J.C. (2007). Synthesis and characterization of a new fluorescent probe for reactive oxygen species. Org. Biomol. Chem. 5, 1454-1458

Inoue, M., Sato, E.F., Nishikawa, M., Park, A.-M., Kira, Y, Imada, I. \& Utsumi, K. (2003). Mitochondrial generation of reactive oxygen species and its role in aerobic life. Current Med. Chem. 10, 2495-2505

Janzen, E.G. (1971). Spin trapping. Acc. Chem. Res. 2, 279-288

Kalai, T., Hideg, E., Vass, I. \& Hideg, K. (1998). Double (fluorescent and spin sensors for detection of reactive oxygen species in the thylakoid membrane). Free Radical. Biol. Med. $24,649-652$

Kim, S., de A Vilela, G. V. M., Bouajila, J., Dias, A. G., Cyrino, F. Z. G. A., Bouskela, E., Costa, P. R. R. \& Nepveu, F. (2007). Alpha-phenyl-N-tert-butyl nitrone (PBN) derivatives: synthesis and protective action against microvascular damages induced by ischemia/reperfusion. Bioorg. Med. Chem. 15, 3572-3578

Kohen, R. \& Nyska, A. (2002). Oxidation of biological systems: oxidative stress phenomena, antioxidants, redox reactions, and methods for their quantification. Toxicol. Pathol. 30, $620-650$

Leavesley, H.B., Li, L., Mukhopadhyay, S., Borowitz, J.L. \& Isom, G.E. (2010). Nitritemediated antagonism of cyanide inhibition of cytochrome c oxidase in dopamine neurons. Toxicol. Sci. 115, 569-576

Lozinsky, E., Shames, A.I. \& Likhtenshtein, G. (2000). Dual fluorophore nitroxides: Models for investigation of intramolecular quenching and novel redox probes. Recent Res. Devel. Photochem. Photobiol. 2, 41-45 
Muller, F.L., Liu, Y. \& Van Remmen, H. (2004). Complex III releases superoxide to both sides of the inner mitochondrial membrane. J. Biol. Chem. 279, 49064-49073

Nieminen, A.L., Saylor, A.K., Herman, B. \& Lemasters, J.J. (1994). ATP depletion rather than mitochondrial depolarization mediates hepatocyte killing after metabolic inhibition. Am. J. Physiol. Cell Physiol. 267, C67-C74

Oodyke, D.L. (1974). Monographs on fragrance raw materials. Food Cosmet. Toxicol. 12, 385405

Ouari, O., Chalier, F., Bonaly, R., Pucci, B. \& Tordo, P. (1998). Synthesis and spin-trapping behaviour of glycosylated nitrones. J. Chem. Soc., Perkin Trans. 2, 2299-2308

Pou, S., Bhan, A., Bhadti, V.S., Wu, S.Y., Hosmane, R.S. \& Rosen, G.M. (1995). The use of fluorophore-containing spin traps as potential probes to localize free radicals in cells with fluorescence imaging methods. FASEB J. 9, 1085-1090

Severin, F.F., Severina, I.I., Antonenko, Y.N., Rokitskaya, T.I., Cherepanov, D.A., Mokhova, E.N., Vyssokikh, M.Y., Pustovidko, A.V., Markova, O.V., Yaguzhinsky, L.S., Korshunova, G.A., Sumbatyan, N.V., Skulachev, M.V. \& Skulachev, V.P. (2010). Penetrating cation/fatty acid anion pair as a mitochondria-targeted protonophore. Proc. Natl. Acad. Sci. U S A. 107,163-168

Skehan, P., Storeng, R., Scudiero, D., Monks, A., McMahon, J., Vistica, D., Warren, J.T., Bokesch, H., Kenney, S. \& Boyd, M.R. (1990). New colorimeric cytotoxicity assay for anticancer-drug screening. J. Natl. Cancer Inst. 82, 1107-1112

Turrens, J.F. (2003). Mitochondrial formation of reactive oxygen species. J. Physiol. 552, 335344

Xu, T., Zanotti' F., Gaballo, A., Raho, G. \& Papa' S. (2000). F1 and Fo connections in the bovine mitochondrial ATP synthase. Eur. J. Biochem. 267, 4445-4455

Walling, C. (1975). Fenton's reagent revisited. Acc. Chem. Res. 8, 125-131 